\title{
Purification of cytidine-triphosphate synthetase from rat liver, and demonstration of monomer, dimer and tetramer
}

\author{
Peedikayil E. Thomas, Barbara J. Lamb and Ernest H.Y. Chu \\ Department of Human Genetics, University of Michigan Medical School, Ann Arbor, MI (U.S.A.)
}

(Received 15 September 1987) Key words: Cytidine-triphosphate synthetase; CTP synthase; Purification; Subunit structure;
Association; Dissociation

Cytidine-triphosphate synthetase (UTP : ammonia ligase (ADP-forming), EC 6.3.4.2.) has been purified over 31000 -fold to homogeneity with $17 \%$ recovery from rat liver cytosol, using high-performance liquid chromatography (HPLC) techniques. The presence of CTP synthetase monomer, dimer and tetramer has been demonstrated in the ammonium sulfate fraction of rat liver cytosol. By gel-permeation HPLC, the molecular weights of the three molecular forms of the enzyme have been estimated as 240000 (tetramer), 120000 (dimer) and 60000 . (monomer). By gel-permeation chromatography on Bio-Gel A-1.5m column, the molecular weights of dimer and monomer were estimated as 100000 and 50000 , respectively. The molecular weight of the monomeric subunit is determined to be 66000 by SDS-polyacrylamide gel electrophoresis. Monomers isolated fresh from 0-30 $\left(\mathrm{NH}_{4}\right)_{2} \mathrm{SO}_{4}$ fraction of rat liver cytosol are enzymatically active. Purified rat liver CTP synthetase exhibited sigmoidal kinetic plots as a function of the substrate UTP in the presence of the end-product, CTP. Partially purified CTP synthetase usually forms an inactive coagulum on freezing and subsequent thawing. Incubation of CTP synthetase dimer at $25^{\circ} \mathrm{C}$ for $1 \mathrm{~h}$ in the presence of UTP, ATP and $\mathrm{Mg}^{2+}$ resulted in optimum conversion to tetramer with least inactivation. The purified tetramer dissociates to dimers when UTP, ATP and $\mathrm{Mg}^{2+}$ are removed by dialysis.

\section{Introduction}

Cytidine-triphosphate synthetase (UTP : ammonia ligase (ADP-forming), EC 6.3.4.2) (CTP synthetase) is a rate-limiting enzyme catalyzing the irreversible reaction; UTP + ATP + Lglutamine $\rightarrow$ L-glutamate + ADP $+\mathbf{P}_{\mathrm{i}}+$ CTP. Both genetic and biochemical approaches have

\footnotetext{
Abbreviations: CTP, cytidine 5'-triphosphate; CTP synthase, cytidine-5'-triphosphate synthetase (EC 6.3.4.2); Hepes, 4-(2hydroxyethyl-1-piperazineethanesulfonic acid; PEP, phosphoenol pyruvate.
}

\footnotetext{
Correspondence: E.H.Y. Chu, Department of Human Genetics, 4708 Med. Sci. II M4708/Box 0618, University of Michigan Medical School, Ann Arbor, MI 48109-0618, U.S.A.
}

been taken by several groups of investigators in an attempt to elucidate the regulation of the activity of the enzyme and its role in pyrimidine metabolism in pro- and eukaryotes. Robert de Saint Vincent and his co-workers $[1,2]$ reported a class of variant Chinese hamster CCL 39 fibroblasts, isolated on the basis of their resistance to cytosine arabinoside and/or excess levels of thymidine, exhibited expanded pools of both CTP and dCTP while their UTP pools were not increased. It was further shown that these variants expressed CTP synthetase activity at the wild-type levels, but the enzyme was less sensitive than the wild-type enzyme to inhibition by CTP [3]. Trudel et al. [4] studied a class of Chinese hamster ovary cell mutants with similar complex phenotypes which 
appeared to be consequence of mutation at the CTP synthetase locus. More recently, resistance to 5-fluorouracil was also shown to be associated with an increased CTP level due to a possible CTP synthetase mutation in V79 Chinese hamster cells [5].

In our laboratory, we have isolated and characterized pleiotropic mutants of Chinese hamster V79 cells with altered CTP synthetase and a complete loss of feedback inhibition by the end product, CTP [6,7]. In addition, we have isolated a series of hamster cell CTP synthetase variants which are resistant to high concentrations of 3deazauridine, exhibit elevated CTP synthetase activity, and are refractory to inhibition by CTP. The activity of CTP synthetase has been shown to be elevated in cancer cells $[8,9]$. CTP synthetase is a target for inhibition by the antitumor agent 3-deazauridine [10], and is possible so for another potent antitumor agent cyclopentenyl cytosine [11-13]. These findings and the availability of CTP synthetase mutants prompted us to purify the enzyme from rat-liver in our attempt to investigate the regulation of gene expression at the transcriptional level, molecular defects of the hamster cell mutants through molecular cloning of the CTP synthetase gene, and the mechanism of action of cyclopentenyl cytosine.

Escherichia coli CTP synthetase has been purified $[14,15]$ and its amino-acid sequence derived from the nucleotide sequence of pyr G [16]. However, the mammalian enzyme has not been purified to homogeneity [17]. $E$. coli CTP synthetase is a dimer $\left(M_{\mathrm{r}} 105000\right)$ which polymerizes to a tetramer $\left(M_{\mathrm{r}} 210000\right)$ in the presence of UTP, ATP and $\mathrm{Mg}^{2+}[18]$. The bovine liver CTP synthetase $\left(M_{\mathrm{r}} 133000\right)$ polymerizes to a larger molecule $\left(M_{\mathrm{r}} 263000\right)$ in the presence of physiologically relevant concentrations of UTP, ATP and $\mathrm{Mg}^{2+}[17,19]$ and it differs from the $E$. coli CTP synthetase in size, structure and properties $[17,19,20]$. Results reported in this paper establish a similarity in subunit structure between the rat and $E$. coli enzymes and further demonstrate the existence of monomer, dimer and tetramer forms of the rat liver enzyme.

\section{Materials and Methods}

Bio-Gel A-1.5m, ammonium sulfate (HPLC grade), and Coomassie brilliant blue R-250 were purchased from Bio-Rad (Rockville Center, NY). Standard marker proteins were from Bio-Rad and Pharmacia (Piscataway, NJ). Polyethyleneimine cellulose thin-layer plates were purchased from Brinkman Instruments (Westbury, New York). [5,6- $\left.{ }^{3} \mathrm{H}\right]$ Uridine 5 -triphosphate tetrasodium salt $35 \mathrm{Ci} / \mathrm{mmol}$ was from ICN Chemical and Radioisotope Division, Irvine, CA. All other reagents were of analytical grade and were obtained from Sigma, St. Louis, MO. Livers were obtained from female Sprague-Dawley rats weighing 60-80 g.

The assay of CTP synthetase is based on the conversion of radioactivity labeled UTP to CTP, followed by the separation of the CTP from other products and substrates by polyethyleneimine cellulose thin-layer chromatography (TLC), as described previously [21]. The $25 \mu \mathrm{l}$ standard reaction mixture contained Hepes ( $\mathrm{pH} 7.4), 100 \mathrm{mM}$; ATP, $8 \mathrm{mM}$; phosphoenol pyruvate (PEP) $8 \mathrm{mM}$; GTP, $4 \mathrm{mM}$; NaF, $10 \mathrm{mM} ; \mathrm{MgCl}_{2}, 20 \mathrm{mM}$; $\beta$-mercaptoethanol, $20 \mathrm{mM}$; UTP, $0.2 \mathrm{mM}$; Lglutamine, $16 \mathrm{mM}$ and $1.1 \cdot 10^{-6} \mathrm{M}\left[5,6{ }^{3} \mathrm{H}\right] \mathrm{UTP}$, $1 \mu \mathrm{Ci}$. Solutions of ATP, UTP, GTP, PEP and L-glutamine were adjusted to $\mathrm{pH} 7.4$ before their addition to the reaction mixture. All assays were done at $37^{\circ} \mathrm{C}$ for $15 \mathrm{~min}$ to $3 \mathrm{~h}$ under linear conditions. $5 \mu 1$ reaction mixture was spotted on a eonditioned polyethyleneimine cellulose TLC sheet, developed in $0.45 \mathrm{M} \mathrm{HCl} .1$ unit of enzyme activity is the amount of enzyme required for the formation of $1 \mu \mathrm{mol}$ of CTP in $1 \mathrm{~h}$.

The protein concentration was determined by the dye-binding procedure of Bradford [22] with reagents from Bio-Rad. Polyacrylamide (12.5\%) gel electrophoresis of the purified CTP synthetase was done in the presence of sodium dodecyl sulfate (SDS) according to Laemmli [23].

\section{Results}

\section{Purification of CTP synthetase}

The following purification procedure described the isolation of CTP synthetase from rat liver. All HPLC steps were carried out at $25^{\circ} \mathrm{C}$. All other procedures were done at $4^{\circ} \mathrm{C}$ unless specified. 
TABLE I

COMPOSITION AND pH OF BUFFER SOLUTIONS USED

\begin{tabular}{|c|c|c|c|c|c|c|c|}
\hline \multirow[t]{2}{*}{ Component } & \multicolumn{7}{|c|}{ Concentration in buffer $(\mathrm{mM})$} \\
\hline & $A$ & B & $\mathrm{C}$ & $\mathrm{D}$ & $\mathrm{E}$ & $F$ & $G$ \\
\hline $\mathrm{KH}_{2} \mathrm{PO}_{4} / \mathrm{K}_{2} \mathrm{HPO}_{4}$ & 200 & 5 & & & 20 & & \\
\hline $\mathrm{NaH}_{2} \mathrm{PO}_{4} / \mathrm{Na}_{2} \mathrm{HPO}_{4}$ & & & & 20 & & 20 & \\
\hline Tris- $\mathrm{HCl}$ & & & 20 & & & & \\
\hline Hepes & & & & & & & 60 \\
\hline $\mathrm{Na}_{2} \mathrm{SO}_{4}$ & & & & 50 & & 50 & \\
\hline EDTA & 1 & 0.5 & & & & & \\
\hline L-glutamine & 2 & 1 & 4 & & & & 4 \\
\hline Dithiothreitol & 2 & 2 & & & 2 & & \\
\hline$\beta$-Mercaptoethanol & & & 20 & 20 & & 20 & 20 \\
\hline UTP & & & & & 0.4 & 0.4 & \\
\hline ATP & & & & & 8 & 8 & \\
\hline $\mathrm{MgCl}_{2}$ & & & & & 10 & 10 & 10 \\
\hline Ethylene glycol & & 4833 & & & & & \\
\hline $\mathrm{pH}$ & 7.5 & 7.5 & 7.4 & 6.8 & 7.5 & 6.8 & 7.4 \\
\hline
\end{tabular}

\section{(1) Preparation of rat liver cytosol}

$370 \mathrm{~g}$ minced rat liver was homogenized (using a Teflon homogenizer) in $870 \mathrm{ml} 0.15 \mathrm{M} \mathrm{KCl} / 0.01$ M Hepes (pH 7.4). The homogenate was centrifuged at $105000 \times \mathrm{g}$ for $60 \mathrm{~min}$ and the clear supernatant $(600 \mathrm{ml})$ was used for ammonium sulfate fractionation.

\section{(2) $\mathrm{O}-30\left(\mathrm{NH}_{4}\right)_{2} \mathrm{SO}_{4}$ fractionation}

Ammonium sulfate $(0.176 \mathrm{~g} / \mathrm{ml}$ of cytosol) was added with slow stirring over a $30 \mathrm{~min}$ period. The resulting precipitate was collected by centrifugation at $27000 \times \mathrm{g}$ for $30 \mathrm{~min}$ and dissolved in a minimum volume of buffer A (Table I).

\section{(3) Hydrophobic interaction high-performance liquid chromatography (Step I)}

The $0-30$ ammonium sulfate fraction was centrifuged at $15000 \times \mathrm{g}$ for $15 \mathrm{~min}$, and the clear supernatant was injected using a $10 \mathrm{ml}$ loop onto a Bio-Gel TSK-phenyl-5-PW column $(150 \times 21.5$ $\mathrm{mm}$, Bio-Rad) that had been equilibrated with buffer $A$. The enzyme was eluted by decreasing the potassium phosphate concentration and increasing the ethylene glycol concentration. This was achieved by applying a $30 \mathrm{~min}$ linear gradient from buffer A to buffer B (containing 30\% ethylene glycol) at a flow rate of $5 \mathrm{ml}$ per min. $5 \mathrm{ml}$ fractions were collected. At $30 \mathrm{~min}$, the gradient was changed from buffer $B$ to distilled water in 15 min, and the column was washed till $60 \mathrm{~min}$. Elution profile of the enzyme is shown in Fig. 1. Fractions containing most of the enzyme activity (fractions No. 22-28) were pooled and concentrated by ammonium sulfate $(0.313 \mathrm{~g} / \mathrm{ml})$ pre-

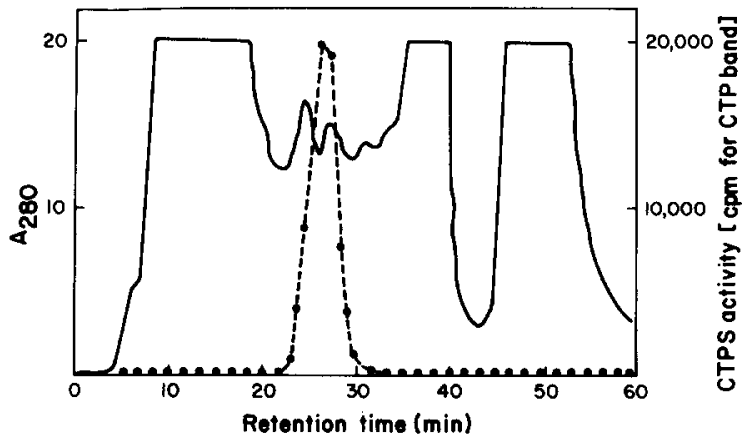

Fig. 1. Elution profile of CTP synthetase on Bio-Gel TSKphenyl-5-PW column $(150 \times 21.5 \mathrm{~mm}$; Bio-Rad $) .10 \mathrm{ml} 0-30$ $\left(\mathrm{NH}_{4}\right)_{2} \mathrm{SO}_{4}$ fraction of rat liver cytosol was injected using a 10 $\mathrm{ml}$ loop. Elution was carried out by applying a 30-min linear gradient from buffer A $(200 \mathrm{mM}$ potassium phosphate $(\mathrm{pH}$ 7.5) $/ 1 \mathrm{mM}$ EDTA $/ 2 \mathrm{mM}$ L-glutamine $/ 2 \mathrm{mM}$ dithiothreitol) to buffer B ( $5 \mathrm{mM}$ potassium phosphate $(\mathrm{pH} 7.4) / 0.5 \mathrm{mM}$ EDTA $/ 1 \mathrm{mM}$ L-glutamine $/ 2 \mathrm{mM}$ dithiothreitol $/ 30 \%$ ethylene glycol) at a flow rate of $5 \mathrm{ml} / \mathrm{min}$. At $30 \mathrm{~min}$ the gradient was changed from buffer $B$ to distilled water in $15 \mathrm{~min}$, and the column was washed with water till $60 \mathrm{~min} . \longrightarrow, A_{280}$; $\bullet-\ldots$, CTP synthetase activity. 


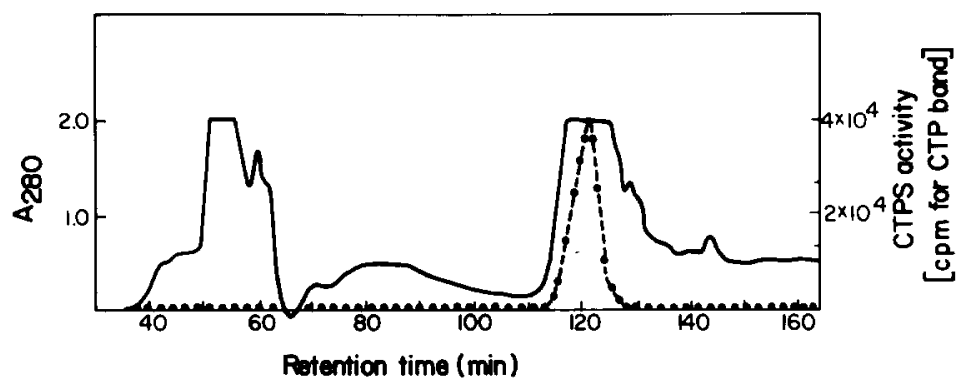

Fig. 2. HPLC anion-exchange chromatography using Bio-Gel TSK-DEAE-5-PW column $(150 \times 21.5 \mathrm{~mm}$; Bio-Rad). $10 \mathrm{ml}$ enzyme concentrate from hydrophobic interaction chromatography was injected using a $10 \mathrm{ml}$ loop. The column was eluted by applying a linear gradient from $20 \mathrm{mM}$ Tris- $\mathrm{HCl}(\mathrm{pH} 7.5) / 4 \mathrm{mM}$ L-glutamine $/ 20 \mathrm{mM} \beta$-mercaptoethanol $/ 0.15 \mathrm{M} \mathrm{NaCl}$ to $20 \mathrm{mM}$ Tris- $\mathrm{HCl}$ (pH 7.5) $/ 4 \mathrm{mM}$ L-glutamine $/ 20 \mathrm{mM} \beta$-mercaptoethanol $/ 0.5 \mathrm{M} \mathrm{NaCl}$ in $180 \mathrm{~min}$ at a flow rate of $1 \mathrm{ml} / \mathrm{min} .-\longrightarrow, A_{280} ; \bullet-\ldots$ -, CTP synthetase activity.

cipitation. The precipitate was dissolved in a minimum volume of buffer $\mathrm{C}$ and dialyzed overnight against the same buffer.

\section{(4) Anion-exchange high-performance liquid chro- matography}

The concentrate of fractions containing enzyme activity from the above step was centrifuged at $15000 \times \mathrm{g}$ for $15 \mathrm{~min}$ and injected using a $10 \mathrm{ml}$ loop onto a Bio-Gel TSK-DEAE-5-PW column $(150 \times 21.5 \mathrm{~mm}$; Bio-Rad) equilibrated with buffer $C$ containing $150 \mathrm{mM} \mathrm{NaCl}$. The enzyme was eluted by increasing the $\mathrm{NaCl}$ concentration to $500 \mathrm{mM}$ in a $180 \mathrm{~min}$ linear gradient at a flow rate of $1 \mathrm{ml} / \mathrm{min}$. The enzyme was eluted in a peak with a retention time of $120 \mathrm{~min}$ (Fig. 2). The fractions containing the enzyme activity (fractions No. 115-126) were pooled and concentrated by ammonium sulfate precipitation. The precipitate was dissolved in a minimum volume of buffer $D$ and dialyzed overnight against the same buffer.

\section{(5) Gel-permeation high-performance chromatogra- phy (Step I)}

The enzyme concentrate from the above step was injected using a $250 \mu \mathrm{l}$ loop onto a Bio-Sil TSK-400 column $(600 \times 7.5 \mathrm{~mm}$; Bio-Rad $)$ equilibrated with buffer $\mathrm{D}$. The column was eluted with the same buffer at $1 \mathrm{ml} / \mathrm{min}$ and $1 \mathrm{ml}$ fractions were collected. The elution profile is shown in Fig. 3. The enzyme is a dimer, and no monomer or tetramer could be detected at this stage of the enzyme purification (see below). The fractions containing enzyme activity (fractions No.
19-21) were pooled and concentrated by ammonium sulfate precipitation as in the previous step. The precipitate was dissolved in a minimum volume of buffer $E$ and dialyzed overnight against the same buffer.

(6) Hydrophobic interaction high-performance liquid chromatography in the presence of UTP, ATP and $\mathrm{Mg}^{2+}$ (Step II)

The enzyme concentrate from the previous step was kept at room temperature for $1 \mathrm{~h}$ and injected using a $250 \mu 1$ loop onto a Bio-Gel TSK-phenyl-5PW column $(75 \times 7.5 \mathrm{~mm}$; Bio-Rad $)$ equilibrated with buffer $\mathrm{E}$. The column was eluted with the

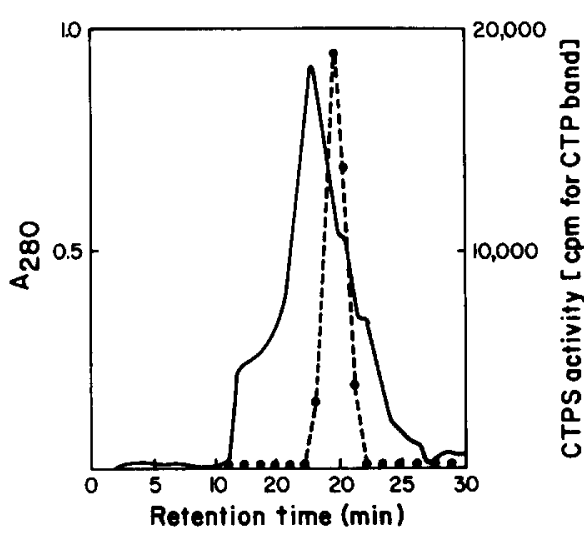

Fig. 3. Gel-permeation high-performance chromatography (Step I) on Bio-Sil TSK-400 (600 $\times 7.5 \mathrm{~mm}$; Bio-Rad). $250 \mu 1$ enzyme concentrate from anion-exchange chromatography was injected using a $250 \mu 1$ loop and eluted with $20 \mathrm{mM}$ sodium phosphate (pH 6.8) $/ 50 \mathrm{mM}$ sodium sulfate $/ 20 \mathrm{mM} \beta$-mercaptoethanol at a flow rate of $1 \mathrm{ml} / \mathrm{min}$, $A_{280}$, - - CTP synthetase activity. 


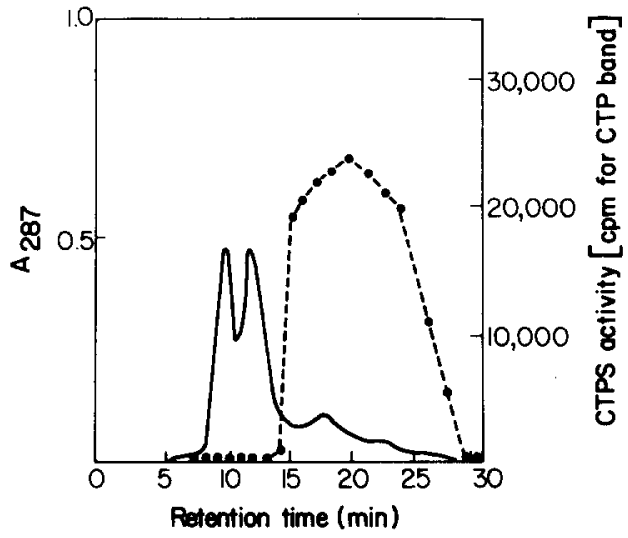

Fig. 4. Hydrophobic interaction HPLC in the presence of UTP, ATP and $\mathrm{Mg}^{2+} .250 \mu \mathrm{l}$ enzyme concentrate from gel filtration (step I) was injected using a $250 \mu 1$ loop onto a Bio-Gel TSK-phenyl-5-PW column $(75 \times 7.5 \mathrm{~mm} ;$ Bio-Rad $)$ equilibrated with $20 \mathrm{mM}$ potassium phosphate buffer $(\mathrm{pH} 7.5) / 0.4$ $\mathrm{mM}$ UTP $/ 8 \mathrm{mM}$ ATP $/ 10 \mathrm{mM} \mathrm{MgCl}_{2} / 2 \mathrm{mM}$ dithiothreitol and eluted with the same buffer at a flow rate of $0.25 \mathrm{ml} / \mathrm{min}$. $-, A_{287}, \bullet-\ldots, \mathrm{CTP}$ synthetase activity.

same buffer at a flow rate of $0.25 \mathrm{ml} / \mathrm{min}$ (Fig. 4). The absorbance at $287 \mathrm{~nm}$ was recorded, since the inclusion of nucleotides gave a high absorbance at $280 \mathrm{~nm}$. Fractions containing the enzyme activity (fractions No. 15-30) were pooled and concentrated using a Micro-Con Filt (negative-pres- sure microconcentrator filtrator from Bio-Molecular Dynamics, Beaverton, OR) and dialyzed against buffer $\mathrm{F}$ for $2 \mathrm{~h}$.

(7) Gel-permeation high-performance chromatography in the presence of UTP, ATP and $\mathrm{Mg}^{2+}$ (Step II)

The enzyme concentrate from the above step was kept at room temperature for $1 \mathrm{~h}$ and injected onto a Bio-Sil TSK-400 column $(600 \times 7.5 \mathrm{~mm}$; Bio-Rad) equilibrated with buffer $F$. The column was eluted with the same buffer and absorbance monitored at $287 \mathrm{~nm}$. The elution profile of the enzyme is shown in Fig. 5. Two peaks of enzyme activity corresponding to tetramers and dimers were obtained; fractions 15-17 contained tetramers. Fraction 18 contained a mixture of tetramers and dimers, and fractions 19-21, dimers. Fractions containing tetramers and dimers were pooled separately and concentrated using a Micro-Con Filt. The enzyme was stored at $-20^{\circ} \mathrm{C}$ after adding glycerol (to $20 \%$ concentration).

Table II summarizes the results of a typical purification of CTP synthetase from rat liver. The enzyme has been purified greater than 31000 -fold. The specific activity and yield are much higher than those reported $\left(0.91 \mu \mathrm{mol} \cdot \mathrm{h}^{-1} \cdot \mathrm{mg}^{-1}\right.$ and

TABLE II

PURIFICATION OF RAT LIVER CTP SYNTHETASE

\begin{tabular}{|c|c|c|c|c|c|c|}
\hline & $\begin{array}{l}\text { Volume } \\
(\mathrm{ml})\end{array}$ & $\begin{array}{l}\text { Total } \\
\text { activity } \\
\text { (unit) }^{\mathrm{a}}\end{array}$ & $\begin{array}{l}\text { Total } \\
\text { protein } \\
(\mathrm{mg})\end{array}$ & $\begin{array}{l}\text { Specific } \\
\text { activity } \\
\text { (unit } / \mathrm{mg} \text { ) }\end{array}$ & $\begin{array}{l}\text { Purification } \\
\text { (-fold) }\end{array}$ & $\begin{array}{l}\text { Yield } \\
(\%)\end{array}$ \\
\hline 1 Rat liver cytosol & 600 & 30.1 & 9345 & 0.0032 & - & 100 \\
\hline $20-30\left(\mathrm{NH}_{4}\right)_{2} \mathrm{SO}_{4}$ fraction & 42 & 30.28 & 1271 & 0.024 & 8 & 100 \\
\hline $\begin{array}{l}3 \text { Concentrate of phenyl-5-PW column } \\
\text { fractions (hydrophobic interaction } \\
\text { chromatography - Step I) }\end{array}$ & 9.2 & 30.15 & 82.9 & 0.363 & 113 & 100 \\
\hline $\begin{array}{l}4 \text { Concentrate of DEAE-5-PW fractions } \\
\text { (anion-exchange chromatography) }\end{array}$ & 1.6 & 15.46 & 10.0 & 1.546 & 483 & 51 \\
\hline $\begin{array}{l}5 \text { Concentrate of gel filtration } \\
\text { (Step I) }\end{array}$ & 1.5 & 14.88 & 2.0 & 7.44 & 2325 & 49 \\
\hline $\begin{array}{l}6 \text { Concentrate of phenyl-5-PW column } \\
\text { fractions (hydrophobic interaction } \\
\text { chromatography Step II) }\end{array}$ & 1.15 & 9.60 & 0.44 & 21.8 & 6770 & 32 \\
\hline 7 Concentrate of gel filtration II & & & & & & \\
\hline Tetramer (Fr. No. 15-17) & 0.7 & 5.15 & 0.051 & 100.98 & 31360 & 17.1 \\
\hline Mixture (Fr. No. 18) & 0.4 & 2.95 & 0.084 & 35.12 & 10907 & 9.8 \\
\hline Dimer (Fr. No. 19-21) & 0.4 & 2.23 & 0.152 & 14.67 & 4556 & 7.4 \\
\hline
\end{tabular}

a 1 unit of enzyme activity is the amount of enzyme required for the formation of $1 \mu \mathrm{mol}$ of CTP in $1 \mathrm{~h}$. 


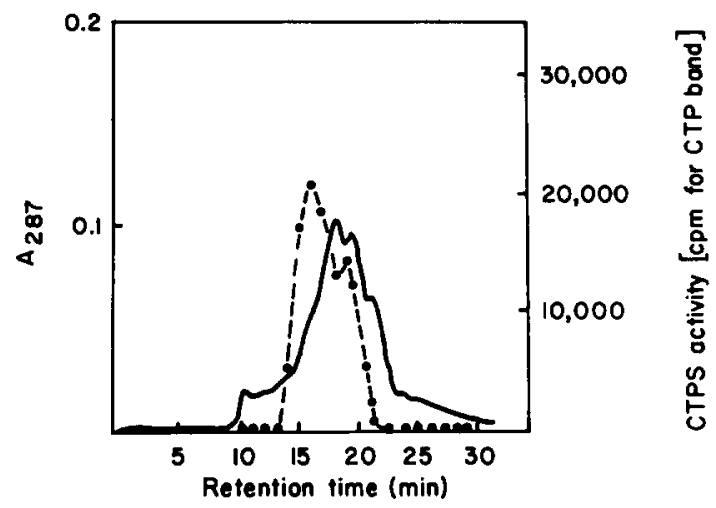

Fig. 5. Gel-permeation HPLC in the presence of UTP, ATP and $\mathrm{Mg}^{2+}$ (Step II). $250 \mu \mathrm{l}$ of the enzyme concentrate from HPLC Step II was injected using a $250 \mu 1$ loop onto a Bio-Sil TSK-400 column $(600 \times 7.5 \mathrm{~mm}$; Bio-Rad) equilibrated with 20 $\mathrm{mM}$ sodium phosphate $(\mathrm{pH} 6.8) / 50 \mathrm{mM}$ sodium sulfate $/ 0.4$ $\mathrm{mM}$ UTP $/ 8 \mathrm{mM}$ ATP $/ 10 \mathrm{mM} \quad \mathrm{MgCl}_{2} / 20 \mathrm{mM} \quad \beta$ mercaptoethanol and eluted with the same buffer at a flow rate of $1 \mathrm{ml} / \mathrm{min}$.,$- A_{287} ;-\ldots-\bullet$, CTP synthetase activity.

$3.4 \%$ ) previously for the bovine enzyme [17]. Polyacrylamide gel electrophoresis of the dialyzed purified enzyme in presence of SDS gave a band corresponding to a molecular weight of 66000 (Fig. 6). The purified enzyme is stable for months when stored at $-20^{\circ} \mathrm{C}$ as described above.

We have observed that the partially purified enzyme at stages 3, 4 and 5 forms inactive coagulum if kept frozen at $-20^{\circ} \mathrm{C}$ and then thawed.

\section{Dissociation of tetramer to dimer}

The purified tetramer was dialyzed for $4 \mathrm{~h}$ against buffer $D$ with two changes of the buffer and $100 \mu 1(120 \mu \mathrm{g})$ was injected onto a Bio-Sil TSK-400 column $(600 \times 7.5 \mathrm{~mm}$; Bio-Rad $)$ equilibrated with the same buffer. Elution was with the same buffer at a flow rate of $1 \mathrm{ml} / \mathrm{min}$. $1-\mathrm{ml}$ fractions were collected and assayed for CTP synthetase activity. The elution profile of the protein coincided with the enzyme activity and the retention time of the CTP synthetase dimer (Fig. 7).

Existence of monomer, dimer and tetramer forms of the CTP synthetase subunit in $\mathrm{O}-30\left(\mathrm{NH}_{4}\right)_{2} \mathrm{SO}_{4}$ fraction of rat liver cytosol

Since the polymerization of CTP synthetase takes place at physiological concentrations of
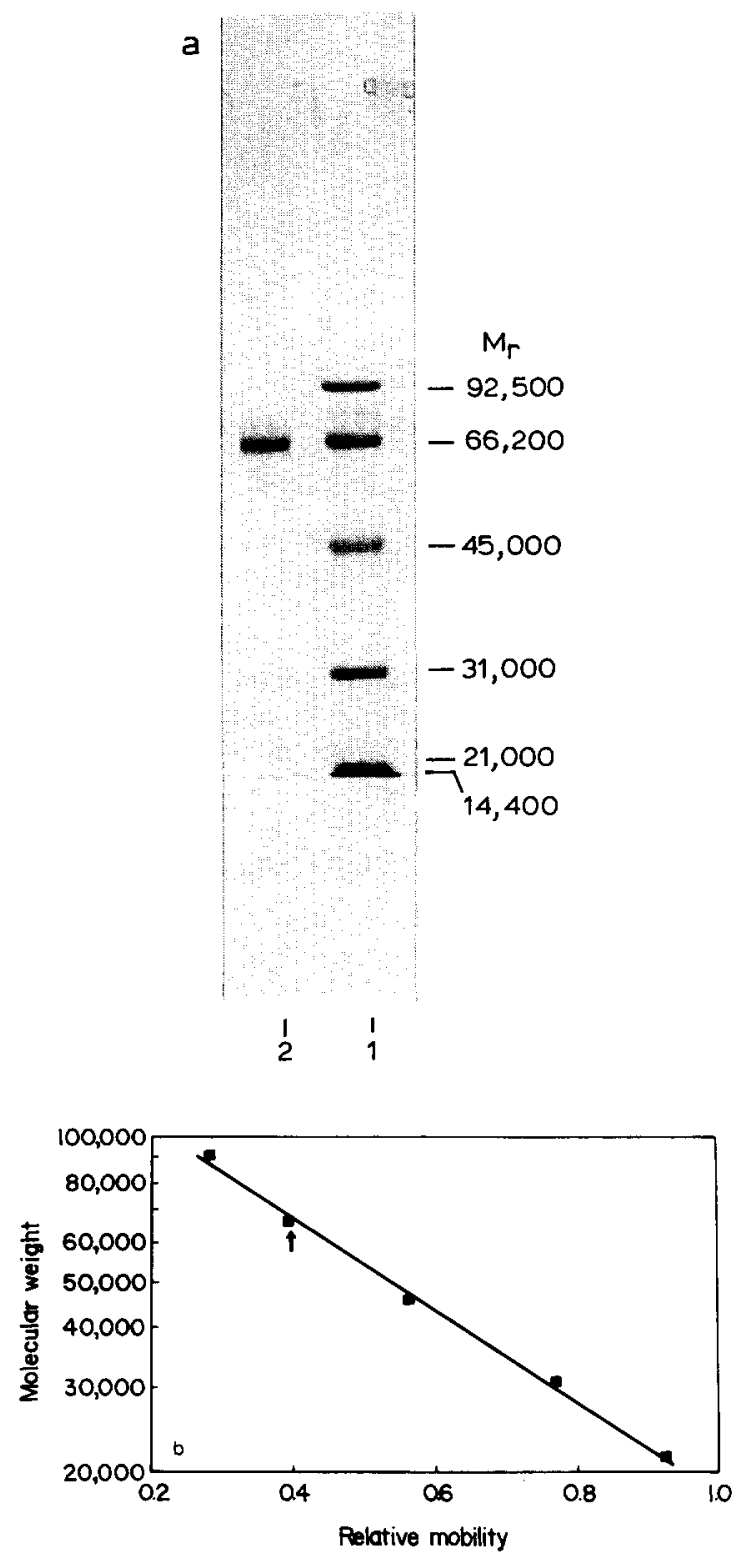

Fig. 6. SDS-polyacrylamide gel electrophoresis. (a) A Coomassie brilliant blue stained gel from SDS-polyacrylamide gel electrophoresis is shown. Lane 1, standard marker proteins of known molecular weights (phosphorylase B, 92500; bovine serum albumin, 66200 ; ovalbumin, 45000; carbonic anhydrase, 31000 ; soybean trypsin inhibitor, 21500 ; and lysozyme, 14400). Lane 2, $5 \mu \mathrm{g}$ dialyzed purified enzyme. (b) Arrow indicates the apparent molecular weight of the protein band corresponding to the CTP synthetase subunit.

nucleotides, it is probable that a substantial fraction of the enzyme exists in a polymerized state in vivo. We were able to isolate monomer, dimer and tetramer forms of the CTP synthetase subunits 


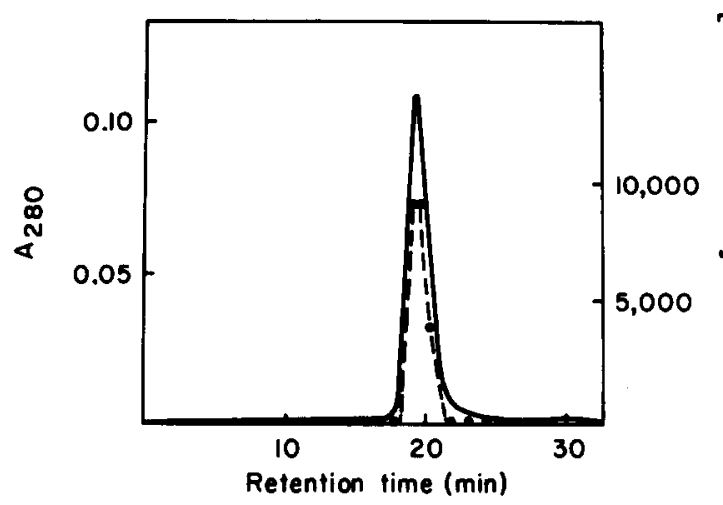

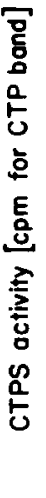

Fig. 7. Gel-permeation HPLC of purified enzyme. $100 \mu 1(120$ $\mu \mathrm{g})$ purified tetramer after dialysis against $20 \mathrm{mM}$ sodium phosphate ( $\mathrm{pH} 6.8) / 50 \mathrm{mM} \mathrm{Na}{ }_{2} \mathrm{SO}_{4} / 20 \mathrm{mM}$ mercaptoethanol was injected onto Bio-Sil TSK-400 column $(600 \times 7.5 \mathrm{~mm}$; Bio-Rad) equilibrated with the same buffer. Elution was with the same buffer at a flow rate of $1 \mathrm{ml} / \mathrm{min}$.,$- A_{280}$; $\bullet-\ldots$, CTP synthetase activity.

from $0-30$ ammonium sulfate fraction of rat liver cytosol. It is difficult to demonstrate the presence of CTP synthetase monomer, dimer and tetramer using cytosol instead of $0-30$ ammonium sulfate fraction of cytosol because of the very low concentration of CTP synthetase in cytosol.

\section{Demonstration of various molecular forms}

(a) By gel-permeation high-performance liquid chromatography. $250 \mu \mathrm{l}$ of $0-30$ ammonium sulfate fraction in buffer $D$ was injected onto a Bio-Sil TSK-400 column $(600 \times 7.5 \mathrm{~mm}$; Bio-Rad) equilibrated with the same buffer. Elution was done with the same buffer at a flow rate of $1 \mathrm{ml} / \mathrm{min}$. $1-\mathrm{ml}$ fractions were collected and assayed for CTP synthetase activity. Three distinct peaks of CTP synthetase activity were obtained (Fig. 8). Fractions 15-17 contained tetramers. Dimers were eluted in fractions 19-20 in the major peak; monomers were eluted in the fractions 22 and 23. The retention time of eight molecular weight standards was determined under identical conditions. The peaks of enzyme activity corresponded to 240000 (tetramer), 120000 (dimer) and 60000 (monomer).

(b) By gel-permeation chromatography on a BioGel A-1.5m column. $1 \mathrm{ml}$ of the $0-30$ ammonium sulfate fraction in buffer $\mathrm{G}$, dialyzed against the same buffer for $2 \mathrm{~h}$ at $4^{\circ} \mathrm{C}$, was layered on a

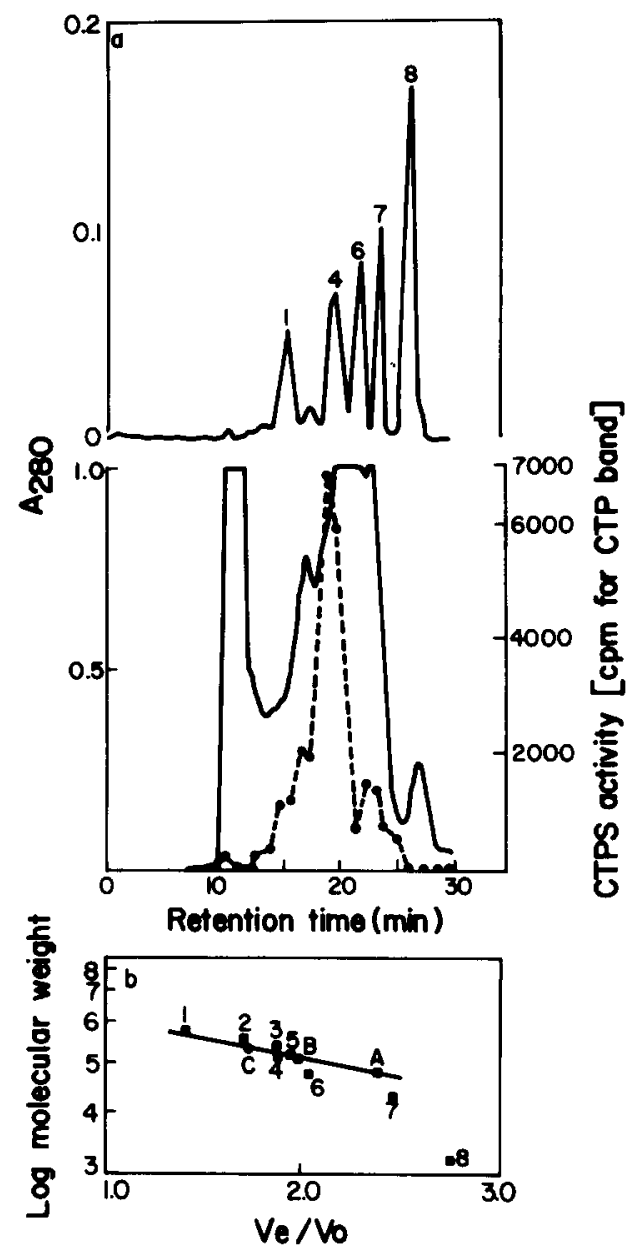

Fig. 8. Gel-permeation HPLC. (a) $250 \mu \mathrm{l} 0-30\left(\mathrm{NH}_{4}\right)_{2} \mathrm{SO}_{4}$ fraction was injected onto a Bio-Sil TSK-400 column $(600 \times 7.5$ $\mathrm{mm}$; Bio-Rad) equilibrated with $20 \mathrm{mM}$ sodium phosphate (pH 6.8) $/ 50 \mathrm{mM} \mathrm{Na}{ }_{2} \mathrm{SO}_{4} / 20 \mathrm{mM} \beta$-mercaptoethanol and eluted with the same buffer at a flow rate of $1 \mathrm{ml} / \mathrm{min}$. $1-\mathrm{ml}$ fractions were collected and assayed for CTP synthetase activity $\mathrm{O} \ldots \ldots$ as described under Materials and Methods and the absorbance at $280 \mathrm{~nm}$ was monitored (solid line). Marker proteins $(1$, thyroglobulin, 670000 ; 2 , ferritin, 440000 ; 3 , catalase, 232000 ; 4, gamma globulin, $158000 ; 5$, aldolase 158000 ; 6, ovalbumin, 44000; 7, myoglobin, 17000 ; and 8 , vitamin B-12, 1350) were applied to the column in three separate experiments and eluted under the same condition as described above. Absorbance at $280 \mathrm{~nm}$ was monitored. (b) Molecular weights of CTP synthetase monomer (A), dimer (B) and tetramer $(C)$ from a semi-logarithmic plot of the data from (A) $\left(V_{0}\right.$ determined from the elution volume of the high-molecularweight protein aggregate).

Bio-Gel A- $1.5 \mathrm{~m}$ column $(95 \times 1.5 \mathrm{~cm})$ equilibrated with the same buffer. Elution was done with the same buffer at a flow rate of $11.2 \mathrm{ml} / \mathrm{h}$ and 


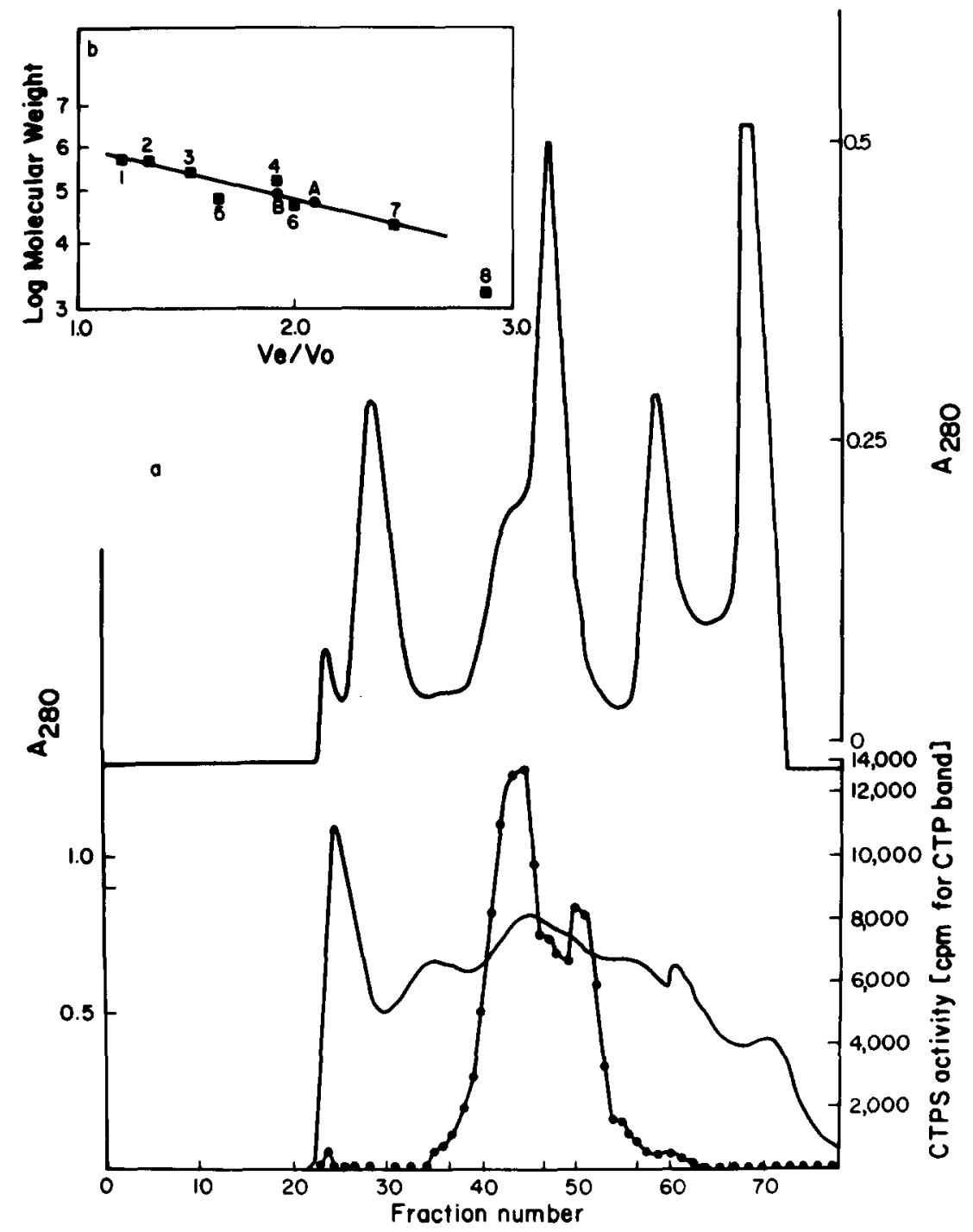

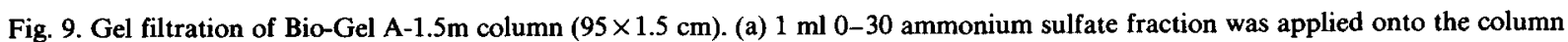
equilibrated with $60 \mathrm{mM}$ Hepes (pH 7.4)/4 mM L-glutamate $/ 10 \mathrm{mM} \mathrm{MgCl} 2 / 20 \mathrm{mM} \beta$-mercaptoethanol. Elution was done with the same buffer at a flow rate of $11.2 \mathrm{ml} / \mathrm{h}$ and $15 \mathrm{~min}$ fraction were collected. Marker proteins of known molecular weights (1, thyroglobulin, 670000;2, ferritin, 440000; 3, catalase 232000; 4, gamma globulin, 158000; 5. bovine serum albumin, 67000; 6, ovalbumin, 44000; 7, myoglobin, 17000; and 8, vitamin B-12, 1350) were applied to the column in three separate experiments and the elution volume at $280 \mathrm{~nm}$ was monitored.,$- A 80 ;-\ldots-C$, CTP synthetase activity. (b) molecular weights of CTP synthetase monomer (A) and dimer (B) from a semi-logarithmic plot of the data from (a) $\left(V_{0}\right.$ determined from the elution volume of high-molecular-weight protein aggregate).

15-min fractions were collected. Absorbance at $280 \mathrm{~nm}$ was recorded using a ultraviolet monitor and a chart recorder. Fractions were assayed for CTP synthetase activity. Two peaks of enzyme activity were obtained (Fig. 9). Eight molecular weight standards were run in three separate experiments under identical conditions and the elu- tion volumes determined. The molecular weights of the dimer and monomer peaks of CTP synthetase activity were estimated to be 100000 and 50000 , respectively, from the graph obtained by plotting log molecular weight against elution volume. 


\section{Optimum conditions for polymerization}

In order to obtain a higher yield of the pure enzyme during purification, we compared the extent of dimer to tetramer conversion of the CTP synthetase concentrate obtained from gel filtration (Step I) under three different conditions. The CTP synthetase concentrate was dialyzed against buffer $\mathrm{F}$ at $4^{\circ} \mathrm{C}$. This was subjected to gel filtration either (i) as such, (ii) after $20 \mathrm{~min}$ incubation at $37^{\circ} \mathrm{C}$, or (iii) after $1 \mathrm{~h}$ at $25^{\circ} \mathrm{C}$. $250 \mu \mathrm{l}$ was injected onto a Bio-Sil TSK-400 column $(600 \times 7.5$

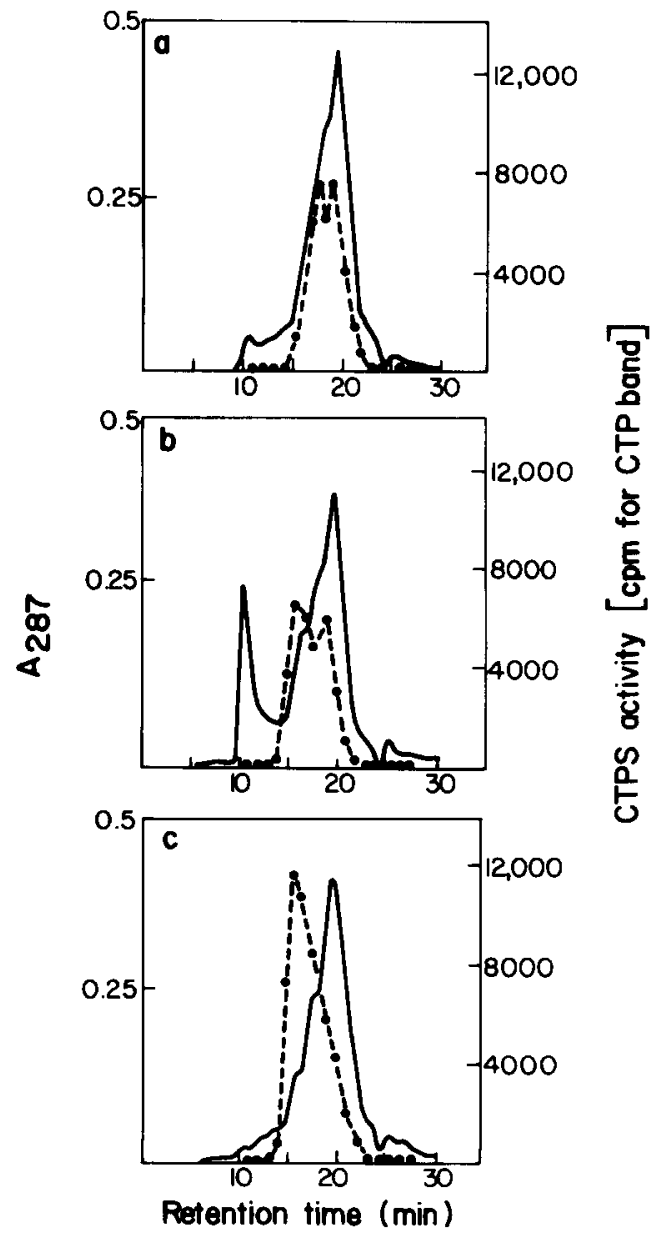

Fig. 10. Optimum conditions for polymerization. The CTP synthetase concentrate from gel filtration step I was dialyzed against $20 \mathrm{mM}$ sodium phosphate $/ 50 \mathrm{mM} \mathrm{Na}{ }_{2} \mathrm{SO}_{4} / 8 \mathrm{mM}$ ATP $/ 10 \mathrm{mM} \mathrm{MgCl} / 20 \mathrm{mM} \beta$-mercaptoethanol (pH 6.8). (a) $250 \mu 1$ was injected onto a Bio-Sil TSK-400 column $(600 \times 7.5$ m); (b) $250 \mu 1$ was injected after incubation at $37^{\circ} \mathrm{C}$ for 20 min; and (c) $250 \mu \mathrm{l}$ was injected after incubation at $25^{\circ} \mathrm{C}$ for $60 \mathrm{~min}$. Elution was done with the same buffer at $1 \mathrm{ml} / \mathrm{min}$. $\longrightarrow, A_{280} ; \bullet-\ldots$, CTP synthetase activity.

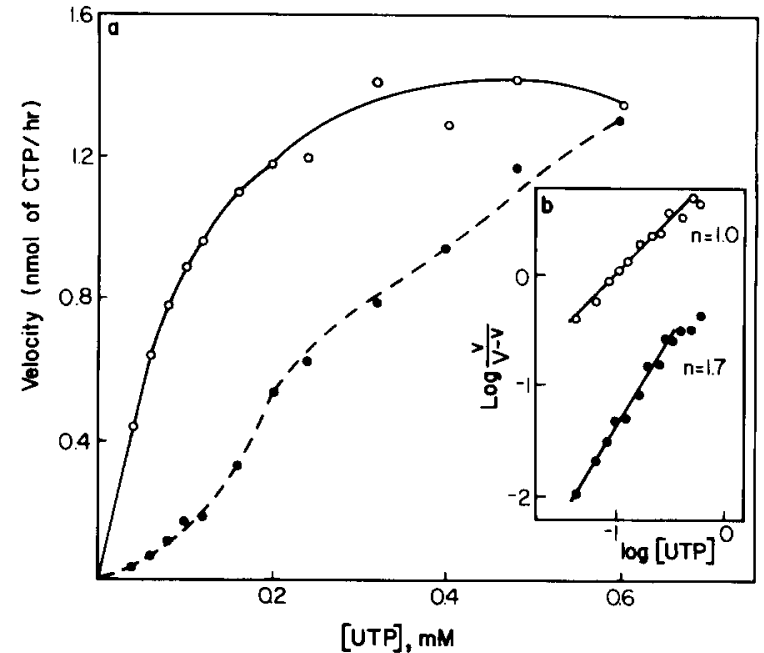

Fig. 11. Velocity of the reaction as a function of UTP concentration in the presence of $0.16 \mathrm{mM} \mathrm{CTP}$ and in its absence. (a) Velocity determined in the presence of $0.16 \mathrm{mM}$ CTP (e) and in its absence $(O)$. All other substrates were kinetically saturating. (b) Hill plot of the data from a. In the presence of $0.16 \mathrm{mM}$ CTP $(\bullet)$ and in its absence $(O)$.

$\mathrm{mm}$ ) equilibrated with the same buffer. The flow rate was $1 \mathrm{ml} / \mathrm{min}$. $1-\mathrm{ml}$ fractions were collected and assayed for CTP synthetase activity. Results are shown in Fig. 10a, b and c. Two peaks of CTP synthetase activity for tetramer and dimer forms were obtained when the enzyme concentrate was injected without preincubation or incubation at $37^{\circ} \mathrm{C}$ for $20 \mathrm{~min}$. The proportion of tetramers was increased after incubation at $37^{\circ} \mathrm{C}$ for $20 \mathrm{~min}$, but some enzyme formed an inactive high-molecularweight aggregate with other proteins that was eluted early as a separate peak under this condition. Incubation for $1 \mathrm{~h}$ at $25^{\circ} \mathrm{C}$ gave predominantly tetramers. However, the conversion of dimer to tetramer was not complete.

The purified rat liver enzyme exhibited sigmoidal kinetics as a function of the substrate UTP in the presence of $0.16 \mathrm{mM} \mathrm{CTP}$ when all other substrates were saturating (Fig. 11). In the absence of CTP, the enzyme showed Michaelis behavior. The Hill coefficient in the presence of CTP was 1.7 and in its absence, 1.0.

\section{Discussion}

Partial purification of bovine liver CTP synthetase did not establish a subunit structure of this 
enzyme [17]. It was reported that the bovine CTP synthetase is a monomer with a molecular weight of 133000 which formed a dimer of molecular weight 263000 in the presence of ATP and UTP [17]. The molecular weight of the $E$. coli CTP synthetase dimer is 105000 , which in the presence of ATP and UTP polymerizes to a tetramer of molecular weight 210000 [18]. The $E$. coli enzyme could be split into a monomeric form each having a molecular weight of 52000 [18]. Weng et al. [16] recently estimated the molecular weight of the $E$. coli CTP synthetase monomer to be 60300 . This raised a question whether the mammalian enzyme has a different structure. Our results clearly show that the rat liver enzyme has monomeric, dimeric and tetrameric structure. The monomer has an approximate molecular weight of 60000 , the dimer of 120000 , and the tetramer of 240000 .

A number of allosteric enzymes associate and dissociate in the presence of ligands. Whereas in some instances polymerization occurs under nonphysiological concentrations of substrates, in other cases it occurs at physiological concentrations [19,24-28]. The association-dissociation phenomenon is also of interest in relation to protein design and subunit interaction [29]. In vitro studies have shown that either ATP or UTP alone added in high enough concentrations can induce tetramerization of E. coli CTP synthetase [28]. Combination of ATP and UTP cause a greatly increased tetramerization compared to each ligand added singly [28].

Anderson [15] reported a purification procedure for the $E$. coli CTP synthetase taking advantage of the differences in the affinity of the associated and dissociated forms of the enzyme for phenyl-Sepharose (hydrophobic support). We have used Bio-Gel TSK-phenyl-5-PW columns. In the first hydrophobic interaction chromatography in the absence of UTP, ATP and $\mathrm{Mg}^{2+}$ the enzyme (a dimer) binds tightly to the hydrophobic support and is eluted by decreasing the ionic strength and including ethylene glycol. However, in the second hydrophobic interaction chromatography in the presence of UTP, ATP and $\mathrm{Mg}^{2+}$, the enzyme (a mixture of dimers and tetramers) seems to have interacted with the column, but is eluted with the same buffer. The purification procedure also exploits of the difference in molecular weight following polymerization of the enzyme in the two gel-filtration steps, e.g., one in the absence and the other in the presence of UTP, ATP and $\mathrm{Mg}^{2+}$. The polymerization of calf liver CTP synthetase occurs in a range of enzyme and substrate concentrations which are approximately those of the physiological system [19]. The concentrations of nucleotides in $\mu \mathrm{mol} / \mathrm{g}$ of wet rat liver have been estimated as 2.44, 0.26, 0.31 and 0.08 for ATP, UTP, GTP and CTP, respectively [30]. Thus, the demonstration of CTP synthetase tetramer in the ammonium sulfate fraction of rat liver cytosol established the occurrence of the tetramer form in vivo.

The monomeric CTP synthetase isolated fresh from the 0-30 ammonium sulfate fraction of rat liver cytosol is in a conformational state that permits its polymerization to active tetrameric form in the presence of substrates in the assay mixture. However, a change in its conformation may result in its inactivation and the monomeric form will no longer be able to form dimers or tetramers. Furthermore, there may exist in vivo an equilibrium among monomer, dimer and tetramer forms of CTP synthetase and the maintenance of this equilibrium may play an important role in the regulation of its activity and consequently pyrimidine metabolism. We have demonstrated that the tetramer is the fully active form of the enzyme and that monomers and dimers are catalytically active. Whether or not the monomer or the dimer per se is catalytically active is not certain, because the activity may be due to tetramers formed in the presence of substrates. Partial dissociation of the enzyme during dialysis followed by the prolonged chromatographic step at $4^{\circ} \mathrm{C}$ may account for the increase in the proportion of monomer obtained by gel filtration using Bio-Gel A-1.5m column.

As in the case of the partially purified bovine liver CTP synthetase [19], the purified rat liver enzyme exhibited sigmoidal kinetic plots as a function of the substrate in the presence of the end product, CTP. From the sigmoidal kinetics in the presence of the end product CTP at low concentrations of UTP in vitro and the actual concentrations of the nucleotides in rat liver, it appears that CTP synthetase offers a useful physiological regulatory mechanism with regard to 
the availability of UTP and CTP for the synthesis of RNA, nucleotide sugars and DNA pyrimidine precursors. When the CTP concentration in the cell is low and the UTP concentration is high, the rate of formation of CTP will be high. High concentration of CTP, on the other hand, will inhibit its further synthesis by acting as a cooperative effector.

The cold lability observed for the partially purified CTP synthetase when stored frozen at $-20^{\circ} \mathrm{C}$ appears to be irreversible due to the formation of a visible coagulum. Under mild conditions, however, the cold lability may be reversible as shown for the E. coli CTP synthetase [15].

\section{Acknowledgements}

We thank Drs. Prasanta Datta, I-Chian Li, and Jules Shafer for their comments and suggestions on the manuscript. We also thank Drs. K.M.J. Menon and V.P. Rajan for allowing us to collect livers from their rats. This research was supported by grant R01 GM20608 from the U.S. Public Health Service.

\section{References}

1 Robert de Saint Vincent, B. and Buttin, G. (1979) Somat. Cell Genet. 5, 67-82.

2 Robert de Saint Vincent, B., Dechamps, M. and Buttin, G. (1980) J. Biol. Chem. 255, 162-167.

3 Robert de Saint Vincent, B. and Buttin, G. (1980) Biochim. Biophys. Acta 610, 352-359.

4 Trudel, M., Van Genechten, T. and Meuth, M. (1984) J. Biol. Chem. 259, 2355-2359.

5 Kaufman, E.R. (1984) Cancer Res. 44, 3371-3376.

6 Chu, E.H.Y., McLaren, J.D., Li, I.-C. and Lamb, B. (1984) Biochem. Genet. 22, 701-715.
7 McLaren, J.D. and Chu, E.H.Y. (1984) Biochem. Genet. 22, 717-727.

8 Genchev, D.D. (1973) Experientia 27, 789-790.

9 Williams, J.C., Kizaki, H., Weber, G. and Morris, H.P. (1978) Nature 271, 71-73.

10 McPartland, R.P., Wang, M.C., Bloch, A. and Weinfeld, H. (1974) Cancer Res. 34, 3107-3111.

11 Glazer, R.I., Knode, M.C., Lim, M.I. and Marquez, V.E. (1985) Biochem. Pharmacol. 34, 2535-2539.

12 Glazer, R.I., Cohen, M.B., Hartman, K.D., Knode, M.C., Lim, M.I. and Marquez, V.E. (1986) Biochem. Pharmacol. 35, 1841-1848.

13 Moyer, J.D., Malinowski, N.M., Treanor, S.P. and Marquez, V.E. (1986) Cancer Res. 46, 3325-3329.

14 Long, C.W. and Pardee, A.B. (1967) J. Biol. Chem. 242 , 4715-4721.

15 Anderson, P.M. (1983) Biochemistry 22, 3285-3292.

16 Weng, M., Makaroff, C.A. and Zalkin, H. (1986) J. Biol. Chem. 261, 5568-5574.

17 McPartland, R.P. and Weinfeld, H. (1976) J. Biol. Chem. $251,4372-4378$.

18 Long, C.W., Levitzki, A. and Koshland, D.E., Jr. (1970) J. Biol. Chem. 245, 80-87.

19 McPartland, R.P. and Weinfeld, H. (1979) J. Biol. Chem. $254,11394-11398$.

20 Savage, C.R. and Weinfeld, H. (1970) J. Biol. Chem. 245, $2529-2535$

21 Levitzki, A. and Koshland, D.E., Jr. (1972a) Biochemistry 11, 241-246.

22 Bradford, M.M. (1976) Anal. Biochem. 72, 248-254

23 Laemmli, U.K. (1970) Nature 227, 680-685.

24 Brown, N.C. and Richard, P. (1969) J. Mol. Biol. 46, 39-55.

25 Constantinides, S.M. and Deal, W.C., Jr. (1969) J. Biol. Chem. 244, 5695-5702.

26 Katsunuma, T., Temma, M. and Katunuma, N. (1968) Biochem. Biophys. Res. Commun. 32, 433-437.

27 Kvamme, E., Tveit, B. and Svenneby, G. (1970) J. Biol. Chem. 245, 1871-1877.

28 Levitzki, A. and Koshland, D.E., Jr. (1972b) Biochemistry $11,247-253$.

29 Klotz, I.M., Langerman, N.R. and Darnall, D.W. (1970) Annu. Rev. Biochem. 39, 25-62.

30 Keppler, D.O.R., Pausch, J. and Decker, K. (1974) J. Biol. Chem. 249, 211-216. 